\title{
Yapı Geçerliliği İçin Doğrulayıcı Faktör Analizi: Uygulamalı Bir Çalışma
}

\author{
Hayriye Esra AKYÜZ* \\ Bitlis Eren Üniversitesi, Fen Edebiyat Fakültesi, İstatistik Bölümü, TR 13000, Bitlis, Türkiye
}

\begin{abstract}
Öz
Bilimsel çalıșmalarda güvenilir sonuçlar elde edebilmek ve standart ölçümler sunabilmek için çalıșmada kullanılan ölçme aracının geçerli olması gerekmektedir. Bu çalışmada Maslach tükenmişlik ölçeğinin yapı geçerliliği test edilerek bir yapısal eşitlik modeli önerilmiştir. Verilerin analizinde IBM SPSS ve AMOS istatistik paket programları kullanılmıştır. Çalışmada elde edilen sonuçlara göre; ölçeğin üç faktör altında toplandığı ve toplam varyansın \% 42.38'ini açıklayabildiği elde edilmiştir. Güvenilirlik analizi sonucunda Cronbach- $\alpha$ katsayısına göre, ölçeğin yüksek bir güvenilirlik düzeyine sahip olduğu belirlenmiştir. Doğrulayıcı faktör analizi ile tek faktörlü, birinci düzey çok faktörlü ve ikinci düzey çok faktörlü modeller ayrı ayrı incelenmiştir. Elde edilen uyum indekslerine göre; bu ölçeğin modellenmesinde modifiye edilmiş birinci düzey çok faktörlü modelin kullanılması önerilmektedir.
\end{abstract}

Anahtar kelimeler: Doğrulayıcı Faktör Analizi, Yapı Geçerliliği, Ölçek.

\section{Confirmatory Factor Analysis for Construct Validity: An Applied Study}

\begin{abstract}
In order to obtain reliable results and to provide standard measurements in scientific studies, the measurement tool must be valid. In this study, construct validity of the Maslach burnout scale was tested and a structural equation model was proposed. IBM SPSS and AMOS statistical package programs were used to analyze the data. According to the results obtained in the study; the scale was collected under three factors and $42.38 \%$ of the total variance could be explained. As a result of the reliability analysis, it was determined that the scale has a high reliability level according to the Cronbach- $\alpha$ coefficient. One-factor, first-level multi-factor and second-level multi-factor models were examined separately by confirmatory factor analysis. According to the obtained fit indices; it is suggested to use a modified first-order multi-factor model in this scale model.
\end{abstract}

Keywords: Confirmatory Factor Analysis, Construct Validity, Scale.

\section{Giriş}

Bilimsel çalışmalarda ortak bir sonuca varabilmek ve güvenilir sonuçlar elde edebilmek için yap1 geçerliliğinin test edilmesi önem arz etmektedir. Ölçümlerde önceden saptanmış bir norm değeri yoksa güvenilirlik ve geçerlilik sorunu gündeme gelir.

Yap1 geçerliliği, ölçekten elde edilen sonucun ve bu sonucun ne ile bağlantılı olduğunun açıklanmasını sağlar. Hazırlanan ölçek maddelerinin belirlenen özellikleri ne derece doğru ölçtüğü ile ilgilidir. Çalışmalarda yapı geçerliliğini test etmek için aykırı (uç) değer analizi, madde analizi, açıklayıcı faktör analizi, güvenilirlik analizi ve doğrulayıcı faktör analizinin (Yapısal Eşitlik Modellemesi) kullanılması önem arz etmektedir.

Aykırı değerler analizinde veri seti içerisindeki aykırı değerler tespit edilir. Daha sonra aykırı değerlerin mevcut olduğu maddeler analizden çıkarılır. Taslak ölçekten elde edilen verilere değişik madde analizleri uygulayarak, her maddenin nihai ölçeğe alınıp alınmayacağına karar verilebilir. Taslak ölçek kişinin kendi geliştirdiği ölçektir. Madde analizi ile ölçekte yer alan maddelerin ayırt edicilik

\footnotetext{
*Sorumlu yazar: heakyuz@beu.edu.tr

Geliş Tarihi: 11.04.2018, Kabul Tarihi: 14.09.2018
} 
güçlerini belirlemeye yönelik, her bir madde için üst grup ve alt grup ortalamaları arasındaki farkın t değerleri hesaplanır. Açıklayıcı faktör analizinin amacı ise değişkenleri boyut haline getirmektir. Faktör analizi sonucunda bir ya da daha fazla alt boyutlar (faktörler) elde etmeyi amaçlanır. Güvenilirlik analizinde genel olarak $\alpha$-katsayısına bağlı olarak ölçeğin güvenilirliği aşağıdaki gibi ifade edilir [1]: $\alpha<0.40$ ise ölçek güvenilir değildir ve yeniden düzenlenmelidir,

$0.40 \leq \alpha<0.50$ ise ölçek çok düşük güvenilirlik düzeyine sahiptir, ölçeğin yeniden düzenlenmesi veya uyarlanmas1 gerekir,

$0.50 \leq \alpha<0.60$ ise ölçek düşük güvenilirlik düzeyine sahiptir, prototip ölçek olarak kullanılması, ancak iyileştirme çalışmalarının yapılması uygun olur,

$0.60 \leq \alpha<0.70$ ise ölçek yeterli güvenilirlik düzeyine sahiptir ve toplum taramalarında kullanılabilir,

$0.70 \leq \alpha<0.90$ ise ölçek yüksek güvenilirlik düzeyine sahiptir, toplum taramalarında ve bilimsel yargıların oluşturulmasında kullanılabilir,

$\alpha \geq 0.90$ ise ölçek çok yüksek güvenilirlik düzeyine sahiptir, fenomen ile ilgili yüksek geçerlik ve güvenilirlikte bilimsel yargıların oluşturulmasında güvenle kullanılabilir.

Açıklayıcı faktör analizi, ölçüm araçlarının yaratılmasında (anket, test vb.), doğrulayıcı faktör analizi (DFA) ise yaratılan bu modellerin çalışılan örneklem üzerinde doğrulanıp doğrulanmadığının test edilmesinde kullanılmaktadır. DFA'nın amacı, $p$ tane gözlenen değişken arasında, gözlenen kovaryansı açıklamak için gizil (latent) faktörlerin küçük bir sayısını bulup değişkenler arasındaki ilişkiyi açıklamaktır. Bu analiz oluşturulan modelin gözlenen ve gözlenemeyen tüm değişkenlerin birlikte testi ile elde edilen sonucun, eldeki verilerle ne derece uyumlu olduğunun ortaya konulmasını sağlar. Hata hesaplamalarında oldukça net sonuçlar ortaya koymaktadır. Geleneksel diğer yöntemler ölçüm hatalarını ayrı ayrı ele alırken; bu analiz, tüm çözümlemelerde ölçüm hatalarını açıkça hesaba katmaktadır [1]. Her bir gözlemlenen değişkene bağlı ölçüm hatası ve gizil değişkenlere bağlı artık hata terimi vardır. Analiz Yapısal Eşitlik Modellemesi (YEM) olarak da bilinir. Yapısal eşitlik modellemesi süreci doğrusal regresyon modelleri, faktör analizi, doğrulayıcı faktör analizi (DFA), yol analizi (path analizi) ve yapısal eşitlik modelleri olarak tanımlanabilir [2].

Analizlerde bir testi karşılaştıracak bir kriter (referans) yoksa yapı geçerliği sınanmalıdır. YEM ya da diğer bir adıyla doğrulayıcı faktör analizi, sosyal bilimler, davranış bilimleri, eğitim bilimleri, ekonomi, pazarlama ve sağlık bilimleri başta olmak üzere birç̧ok bilim dalı tarafindan kullanılan, belirli bir teoriye dayalı olarak gözlenebilen ve gözlenemeyen değişkenlerin nedensel ve ilişkisel bir model içinde tanımlanmasına dayanan, konu ile ilgili yapısal kuramın çok değişkenli analizine hipotez testi yaklaşımı getiren istatistiksel yöntemler dizisidir [3,4].

YEM, faktör analizi ve çok değişkenli regresyon analizinin birleşmesiyle meydana gelen çok değişkenli analiz yöntemidir. YEM analizi, oluşturulan modelin gözlenen ve gözlenemeyen tüm değişkenlerin birlikte testi ile elde edilen sonucun, eldeki verilerle ne derece uyumlu olduğunun ortaya konulmasını sağlar. Modelin test edilmesiyle elde edilen uyum indeksleri model ile veri arasında uyum olduğunu gösteriyorsa, yapısal olarak oluşturulan hipotezler kabul edilmekte, uyum indeksleri böyle bir uyumun var olmadığını ortaya koyuyorsa hipotezler reddedilmektedir. İlk olarak YEM, açıklayıcı bir yaklaşım yerine, doğrulayıcı bir yaklaşımı benimsemektedir. YEM dışındaki çok çeşitli istatistiksel yöntemler veri seti üzerindeki ilişkileri keşfetmeye çalışırken; YEM, kuramsal olarak varlığı kurulmuş olan ilişkilerin veri ile uyumunu doğrulamaktadır [5]. YEM, hata hesaplamalarında oldukça net sonuçlar ortaya koymaktadır.

Yöntemin yeni birçok alanda hizmet vermesi sebebiyle literatürde birçok alan uygulamalarının yer aldığı çalışma bulunmaktadır. Ülkemizde son yıllarda yapılan YEM çalışmaları da sürekli bir artış göstermektedir. Sönmez ve Ülker [6], Van'da bulunan Tir buğdayı olarak ifade edilen buğdayın tane verimini etkileyen verim öğelerini belirlemişlerdir. Yılmaz [7] tüketici şikayetleri üzerine bir çalıșma yapmıştır. Ayrıca Ankara'da dinlenme evinde yaşayan yaşlıların yaşam doyumunu etkileyen faktörler K1lınç [8] tarafindan incelenmiştir. Yılmaz ve Çelik [9] bankacılık sektöründe müşteri memnuniyeti ve bağlılık arasındaki ilişkiyi ele almışlardır. Başka bir çalışmada üniversite öğrencilerinin yaşadıkları stres verici olaya dayalı olarak yaptıkları olayın bilişsel değerlendirilmesi yapılmıştır [10]. Türkiye'deki ilçeler için halen kullanılan gelişmişlik indeksinin doğrulanması ve söz konusu indekslerin doğrulanmaması durumunda kullanılabilecek yeni indeksin bulunması için bir çalışma yapılmıştır [11]. Çerezci [12], yapısal eşitlik modelleri ve kullanılan uyum iyiliği indekslerinin karşılaştırılması üzerine bir çalışma yapmıştır. Marsh ve ark. [13], açıklayıcı ve doğrulayıcı faktör analizlerinin bir birleşimi 
olarak açıklayıcı yapısal eşitlik modeli üzerine çalışmışlardır. Alkış [14], bayes YEM üzerine çalışma yapmıştır. Karagöz ve Ağbektaş [15], YEM ile yaşam memnuniyeti ölçeği geliştirmişlerdir. Karagöz ve ark. [16], sağlik hizmetlerinin hastalarda meydana getirdiği memnuniyeti belirleyebilecek bir ölçek geliştirmiş ve ölçeği geliştirebilmek için YEM'den faydalanmışlardır. Uygungil [17] pozitif psikolojik sermayenin olumlu çalışan tutumları olarak örgütsel bağl1lık ve iş tatmini; olumsuz çalışan tutumları olarak örgütsel sinizm ve işten ayrılma niyeti üzerindeki etkilerini araştırmıştır. Samancı [18] örgütsel ve kişisel öncülleri bağlamında örgütsel vatandaşlık davranışı için bir model önerisinde bulunmuşlardır. Topçu ve ark. [19] zorunlu örgütsel vatandaşlık davranışı, örgütsel sinizm ve iş tatmininin çalışanların bireysel iş performanslarına olan etkileri araştırmışlardır. Kıran [20], örgütsel sinizm ve işe gömülü olmanın psikolojik sermayenin işten ayrılma niyeti üzerindeki etkisindeki aracılık rollerinin tespit edilmesi üzerine çalışmıştır.

$\mathrm{Bu}$ çalışmada Maslach tükenmişlik ölçeğinin yapı geçerliliği test edilerek bir yapısal eşitlik modeli önerilmiştir. Ayrıca, yapı geçerliliğinin testinde kullanılması gereken aykırı uç değerler analizi, madde analizi, açıklayıcı faktör analizi, güvenilirlik analizi ve doğrulayıcı faktör analizi uygulamalı olarak gösterilmeye çalış1lmıştır.

\section{Maslach Tükenmişlik Ölçeği}

Tükenmişlik ile ilgili birçok araştırmacı tarafindan farklı tanımlamalar yapılmıştır. Maslach ve Jackson [21] tükenmişliği zihinsel fiziksel ve duygusal bir tükenme sendromu olarak tanımlamışlardır. Daha sonra; Maslach tükenmişlik ölçeğinin yapı geçerliliği faktör yapısının incelenmesiyle ele alınarak, yapılan faktör analizi sonucunda üç faktör olarak elde edilmiştir. Bu faktörler duygusal tükenme, duyarsızlaşma ve kişisel başarıdır. Her bir faktör altında farklı maddeler yer almaktadır. Duygusal tükenme faktörü altında M1, M2, M3, M6, M8, M13, M14, M16 ve M20; duyarsızlaşma faktörü altında M5, M10, M11, M15 ve M22; kişisel başarı faktörü altında M4, M7, M9, M12, M17 ve M18 maddeleri yer almaktadır.

Maddeler; hiçbir zaman: 0 ve her zaman: 6 olmak üzere 7'li derecelendirme ile yanıtlanmaktadır. Bu çalışmada; ölçeğin beş seçenekli şekli kullanılmıştır. Duygusal tükenme ve duyarsızlaşma alt ölçek puanları, her bir madde için hiçbir zaman: 0 , çok nadir: 1 , bazen: 2 , çoğu zaman: 3 ve her zaman: 4 olarak puanlandırılmakta, kişisel başarı alt ölçek puanları ise bunun tersi şeklindedir $[21,22]$.

\section{Materyal ve Metot}

Kesitsel tipteki bu araştırmanın yığınını; Elazığ il merkezindeki devlet ilköğretim okullarında görev yapan 2218 öğretmen oluşturmuştur. 62 ilköğretim okulu arasındaki 47 okulda, yığın temsil edilecek biçimde tabakalı örnekleme yöntemi ile 316 öğretmene ulaşılmıştır. Okul ve öğretmenlerin seçiminde homojenlik esas alınıp, her okuldan kaç öğretmene ulaşlacağı orantılı seçim metoduyla belirlenmiştir. Bu çalışma; Fırat Üniversitesi Tıp Fakültesi Etik Kurulu ve İl Milli Eğitim Müdürlüğü'nden gerekli izinler alınarak gerçekleştirilmiştir. Öğretmenlere; demografik özellikler, mesleki bilgiler ve memnuniyeti içeren 18 soru ve Maslach tükenmişlik ölçeğinden oluşan anket uygulanmıştır. Verilerin analizinde SPSS ve AMOS paket programları kullanılmıştır.

Yığındaki birey sayısı bilindiğinden dolayı örnek sayısı,

$$
n=\frac{\mathrm{N} \mathrm{t}^{2} \mathrm{pq}}{\mathrm{d}^{2}(\mathrm{~N}-1)+\mathrm{t}^{2} \mathrm{pq}}
$$

formülü ile elde edilmiştir [23]. N; yığındaki birey sayısını (2218), n; örnekleme alınacak birey sayısını, p; incelenen olayın görülüş sıklığını (0.40), q; incelenen olayın görülmeyiş $(0.60)$ sıklı̆̆ını, t; belirli serbestlik derecesinde ve saptanan yanılma düzeyinde $t$ tablosundan bulunan teorik değeri (1.96) ve $d$ ise olayın görülüş sıklığına göre yapılmak istenen sapmayı (0.05) belirtmektedir. 


\section{Bulgular}

Çalışmaya katılan öğretmenlere ait demografik özellikler Tablo 1'de gösterilmiştir.

Tablo 1. Araştırmaya katılan öğretmenlerin demografik özellikleri

\begin{tabular}{|c|c|c|}
\hline Demografik özellikler & Örnek hacmi (n) & $(\%)$ \\
\hline \multicolumn{3}{|l|}{ Cinsiyet } \\
\hline Kadın & 128 & 40.5 \\
\hline Erkek & 188 & 59.5 \\
\hline \multicolumn{3}{|l|}{ Yaş grupları } \\
\hline $22-28$ & 42 & 13.3 \\
\hline $29-35$ & 68 & 21.5 \\
\hline $36-42$ & 101 & 32.0 \\
\hline $43-49$ & 56 & 17.7 \\
\hline 50 yaş ve üzeri & 49 & 15.5 \\
\hline \multicolumn{3}{|l|}{ Medeni durum } \\
\hline Evli & 271 & 85.8 \\
\hline Bekâr & 41 & 13.0 \\
\hline Dul/boşanmış & 4 & 1.3 \\
\hline \multicolumn{3}{|l|}{ Mezun olduğu okul } \\
\hline Lise & 3 & 0.90 \\
\hline Ön lisans & 60 & 19.0 \\
\hline Fakülte & 217 & 68.7 \\
\hline Lisansüstü & 36 & 11.4 \\
\hline \multicolumn{3}{|l|}{ Çalışma süresi } \\
\hline 1 y1l alt1 & 40 & 12.7 \\
\hline $1-3$ y1l & 66 & 20.9 \\
\hline $4-6$ yil & 64 & 20.3 \\
\hline 7 yil ve üzeri & 146 & 46.2 \\
\hline \multicolumn{3}{|l|}{ Mesleki kıdem } \\
\hline 5 y1l ve daha az & 41 & 13.0 \\
\hline $6-10$ y1l & 38 & 12.0 \\
\hline $11-15 \mathrm{yll}$ & 94 & 29.7 \\
\hline $16-20 \mathrm{yil}$ & 50 & 15.8 \\
\hline $21-25$ yil & 39 & 12.3 \\
\hline 26 yıl ve üzeri & 54 & 17.1 \\
\hline \multicolumn{3}{|l|}{ Haftalık ders saati } \\
\hline 20 saat ve altı & 34 & 10.8 \\
\hline 21-30 saat & 260 & 82.3 \\
\hline 31 saat ve üzeri & 22 & 7.0 \\
\hline Toplam & 316 & 100.0 \\
\hline
\end{tabular}

Çalışmada 316 öğretmenin demografik özellikleri göz önüne alındığında; katılımcıların \% 59.5'i erkek, \% 40.5'i kadın, çoğunluğu 36-42 yaş aralığında (\% 32.0), \% 85.8'i evli, \% 13.0'ü bekâr ve \% 1.3'nün ise dul/boşanmiş, \% 68.7'sinin fakülte mezunu olduğu belirlenmiştir. Öğretmenlerin \% 46.2'si 7 yıl veya daha uzun süre aynı kurumda çalıştığı, \% 29.7'si 11-15 yıllık kıdeme ve \% 82.3'ünün ise haftada 21-30 saat arası ders yüküne sahip olduğu görülmüştür (Tablo 1).

Araştırmaya katılan 316 katılımcıya ait veriler incelendiğinde; hangi değerlerin uç değer olduğunu belirleyebilmek için Uç değer analizi yapılmış olup 28. ve 38. katılımcının aşırı değerlere sahip olduğu görülmüştür. Ölçeğe ait toplam puan ortalamasının Normallik varsayımının sağlayıp sağlamadığı Uyum iyiliği testleri ile incelenmiş ve Tablo 2'deki gibi elde edilmiştir.

Tablo 2. Uyum iyiliği testi sonuçları

\begin{tabular}{lcccccc}
\hline & \multicolumn{3}{c}{ Kolmogorov-Smirnov } & \multicolumn{3}{c}{ Shapiro-Wilk } \\
\cline { 2 - 7 } & $\begin{array}{c}\text { İstatistik } \\
\text { değeri }\end{array}$ & $\begin{array}{c}\text { Serbestlik } \\
\text { derecesi }\end{array}$ & $p$-değeri & $\begin{array}{c}\text { İstatistik } \\
\text { değeri }\end{array}$ & $\begin{array}{c}\text { Serbestlik } \\
\text { derecesi }\end{array}$ & $p$-değeri \\
\cline { 2 - 8 } Ortalama toplam skor & 0.081 & 314 & 0.000 & 0.986 & 314 & 0.004 \\
\hline
\end{tabular}


Tablo 2 incelendiğinde toplam puan ortalamasının Normal dağılım ile uyumlu olmadı̆̆ görülmüştür $(\mathrm{p}<0.05)$. Bu sonuç, aykırı değerlerin varlığından kaynaklanmaktadır. Madde analizi sonuçları Tablo 3'de verilmiştir.

Tablo 3. Madde-toplam (Item- total) istatistikleri

\begin{tabular}{lccccc}
\hline & $\begin{array}{c}\text { Scale Mean if Item } \\
\text { Deleted }\end{array}$ & $\begin{array}{c}\text { Scale Variance if } \\
\text { Item Deleted }\end{array}$ & $\begin{array}{c}\text { Corrected Item- } \\
\text { Total Correlation }\end{array}$ & $\begin{array}{c}\text { Squared Multiple } \\
\text { Correlation }\end{array}$ & $\begin{array}{c}\text { Cronbach's Alpha if } \\
\text { Item Deleted }\end{array}$ \\
\hline M1 & 24.1306 & 75.187 & 0.491 & 0.424 & 0.780 \\
M2 & 23.5287 & 75.758 & 0.483 & 0.464 & 0.781 \\
M3 & 24.1943 & 76.636 & 0.461 & 0.349 & 0.783 \\
M4 & 24.4045 & 83.449 & 0.044 & 0.165 & 0.804 \\
M5 & 24.5573 & 78.062 & 0.417 & 0.250 & 0.785 \\
M6 & 24.2739 & 77.592 & 0.423 & 0.374 & 0.785 \\
M7 & 24.2420 & 82.561 & 0.087 & 0.215 & 0.803 \\
M8 & 24.1338 & 74.327 & 0.499 & 0.442 & 0.779 \\
M9 & 24.6306 & 79.818 & 0.237 & 0.227 & 0.795 \\
M10 & 25.1369 & 78.400 & 0.460 & 0.322 & 0.784 \\
M11 & 24.8185 & 76.999 & 0.454 & 0.298 & 0.783 \\
M12 & 24.3503 & 77.596 & 0.439 & 0.329 & 0.784 \\
M13 & 24.2994 & 73.469 & 0.568 & 0.427 & 0.775 \\
M14 & 23.2420 & 82.312 & 0.051 & 0.219 & 0.810 \\
M15 & 24.8631 & 81.192 & 0.153 & 0.117 & 0.800 \\
M16 & 24.1879 & 74.645 & 0.467 & 0.361 & 0.781 \\
M17 & 24.6497 & 79.340 & 0.315 & 0.358 & 0.790 \\
M18 & 24.5255 & 77.860 & 0.383 & 0.377 & 0.787 \\
M19 & 24.3408 & 79.804 & 0.279 & 0.306 & 0.792 \\
M20 & 24.1911 & 75.312 & 0.569 & 0.524 & 0.777 \\
M21 & 24.2038 & 79.236 & 0.284 & 0.212 & 0.792 \\
M22 & 24.6624 & 81.049 & 0.203 & 0.260 & 0.796 \\
\hline
\end{tabular}

Tablo 3 incelendiğinde, düzeltilmiş madde-toplam korelasyon (Corrected Item-Total Correlations) değeri 0.20 'nin altında olan M4, M7, M14 ve M15 maddeleri çıkarılarak Madde analizi tekrarlanmıştır. Analiz tekrar yapıldıktan sonra M22 maddesine ait korelasyon değerinin 0.20'nin altında olması sebebiyle bu madde çıarılmış ve son olarak tekrar madde analizi yapılmış ve sonuçlar Tablo 4'de verilmiştir.

Tablo 4. Uygun olmayan maddelerin çıkarıldığı durumda madde-toplam (Item- total) istatistikleri i. madde silindiğinde i.madde silindiğinde $\quad$ Madde-bütün $\quad$ Çoklu $\quad$ i.madde silindiğinde ölçek ortalaması ölçek varyansı korelasyonları korelasyonların güvenilirlik

\begin{tabular}{lllllc} 
& & & karesi & katsay1S1 \\
\hline M1 & 18.0287 & 60.974 & 0.520 & 0.400 & 0.818 \\
M2 & 17.4268 & 61.421 & 0.518 & 0.446 & 0.818 \\
M3 & 18.0924 & 62.768 & 0.459 & 0.331 & 0.822 \\
M5 & 18.4554 & 64.236 & 0.401 & 0.224 & 0.825 \\
M6 & 18.1720 & 63.152 & 0.456 & 0.363 & 0.822 \\
M8 & 18.0318 & 60.031 & 0.537 & 0.410 & 0.817 \\
M9 & 18.5287 & 65.662 & 0.233 & 0.165 & 0.835 \\
M10 & 19.0350 & 64.865 & 0.416 & 0.261 & 0.825 \\
M11 & 18.7166 & 63.130 & 0.449 & 0.282 & 0.822 \\
M12 & 18.2484 & 63.171 & 0.473 & 0.293 & 0.821 \\
M13 & 18.1975 & 59.820 & 0.571 & 0.407 & 0.815 \\
M16 & 18.0860 & 61.344 & 0.441 & 0.328 & 0.823 \\
M17 & 18.5478 & 65.277 & 0.308 & 0.332 & 0.830 \\
M18 & 18.4236 & 63.727 & 0.391 & 0.358 & 0.826 \\
M19 & 18.2389 & 65.531 & 0.284 & 0.256 & 0.831 \\
M20 & 18.0892 & 61.078 & 0.605 & 0.501 & 0.814 \\
M21 & 18.1019 & 64.999 & 0.289 & 0.193 & 0.831 \\
\hline
\end{tabular}


Sonuç olarak, madde analizi sonucunda M4, M7, M14, M15 ve M22 maddeleri analizden çıkarılmış olup korelasyon değerlerinin 0.20 'nin üstünde olduğu belirlenmiştir.

Tablo 5. Hotelling's $T^{2}$ testi

\begin{tabular}{cc}
\hline Test istatistiği & \\
\hline Hotelling's T $^{2}$ & 774.326 \\
F- testi & 46.076 \\
\hline$p$-değeri & 0.000 \\
\hline
\end{tabular}

Tablo 5'de yer alan Hotelling's $\mathrm{T}^{2}$ istatistiği incelendiğinde ölçekte birden fazla alt boyut olduğu ve ölçeğe verilen cevapların birbirinden farklı olduğu belirlenmiştir $(\mathrm{p}<0.05)$.

Madde analizinin ikinci kısmında, toplam puan ortalamasının \%27'lik alt ve üst sınırları ile maddeler arasında istatistiksel olarak anlamlı bir farklılık olup olmadığını belirleyebilmek için Bağımsız örnekler ile iki ortalama farkına ilişkin t-testi kullanılmıştır ve sonuçlar Tablo 6'daki gibi elde edilmiştir.

Tablo 6. Bağımsız iki grup t-testi sonuçları

\begin{tabular}{|c|c|c|c|c|}
\hline \multirow[b]{2}{*}{ Madde* } & \multicolumn{2}{|c|}{ Levene testi } & \multicolumn{2}{|c|}{ t-testi } \\
\hline & F-testi & p-değeri & t-testi & $p$-değeri \\
\hline \multirow{2}{*}{ M1 } & \multirow{2}{*}{1.857} & \multirow{2}{*}{0.175} & -11.743 & 0.000 \\
\hline & & & -11.743 & 0.000 \\
\hline \multirow{2}{*}{ M2 } & \multirow{2}{*}{0.262} & \multirow{2}{*}{0.609} & -10.457 & 0.000 \\
\hline & & & -10.457 & 0.000 \\
\hline \multirow{2}{*}{ M3 } & \multirow{2}{*}{0.189} & \multirow{2}{*}{0.665} & -10.087 & 0.000 \\
\hline & & & -10.087 & 0.000 \\
\hline \multirow{2}{*}{ M5 } & \multirow{2}{*}{9.187} & \multirow{2}{*}{0.003} & -8.057 & 0.000 \\
\hline & & & -8.057 & 0.000 \\
\hline \multirow{2}{*}{ M6 } & \multirow{2}{*}{0.004} & \multirow{2}{*}{0.949} & -8.532 & 0.000 \\
\hline & & & -8.532 & 0.000 \\
\hline \multirow{2}{*}{ M8 } & \multirow{2}{*}{0.758} & \multirow{2}{*}{0.385} & -11.625 & 0.000 \\
\hline & & & -11.625 & 0.000 \\
\hline \multirow{2}{*}{ M9 } & \multirow{2}{*}{4.494} & \multirow{2}{*}{0.035} & -5.817 & 0.000 \\
\hline & & & -5.817 & 0.000 \\
\hline \multirow{2}{*}{ M10 } & \multirow{2}{*}{78.246} & \multirow{2}{*}{0.000} & -8.932 & 0.000 \\
\hline & & & -8.932 & 0.000 \\
\hline \multirow{2}{*}{ M11 } & \multirow{2}{*}{42.652} & & -10.296 & 0.000 \\
\hline & & 0.000 & -10.296 & 0.000 \\
\hline M12 & 1260 & 0263 & -9.485 & 0.000 \\
\hline & & & -9.485 & 0.000 \\
\hline M13 & 9946 & 0007 & -14.498 & 0.000 \\
\hline $1 \mathrm{VHIJ}$ & 9.940 & 0.002 & -14.498 & 0.000 \\
\hline M16 & 0348 & 0556 & -11.596 & 0.000 \\
\hline 10110 & & 0.530 & -11.596 & 0.000 \\
\hline M17 & 0593 & 0.442 & -7.288 & 0.000 \\
\hline 1017 & 0.593 & 0.442 & -7.288 & 0.000 \\
\hline M18 & 2093 & 0150 & -7.884 & 0.000 \\
\hline 1718 & 2.093 & 0.150 & -7.884 & 0.000 \\
\hline M19 & 2884 & 0.091 & -6.180 & 0.000 \\
\hline & & & -6.180 & 0.000 \\
\hline M20 & 0323 & 0570 & -13.157 & 0.000 \\
\hline 10120 & & $0.5 / 0$ & -13.157 & 0.000 \\
\hline M21 & 0261 & 0610 & -6.970 & 0.000 \\
\hline & 0.201 & 0.010 & -6.970 & 0.000 \\
\hline
\end{tabular}

": Her bir madde için ilk satır varyansların homojen olduğu, ikinci satır ise varyansların homojen olmadığı durumu ifade etmek tedir. 
Tablo 6 incelendiğinde maddeler ile gruplar arasında istatistiksel olarak anlamlı bir farklılık olduğu belirlenmiştir $(\mathrm{p}<0.05)$. Bu durum bize her bir maddenin ayırt edicilik özelliğinin olduğunu göstermektedir.

Tablo 7. KMO ve Bartlett testi sonuçları

\begin{tabular}{llc}
\hline & Kaiser-Meyer-Olkin (KMO) & 0.845 \\
\hline \multirow{3}{*}{ Bartlett Küresellik testi } & Ki-kare & 974.127 \\
& Serbestlik derecesi & 66 \\
& $p$-değeri & 0.000 \\
\hline
\end{tabular}

KMO değerinin 0.70 'den büyük olması istenir. Bu test bize veri setinin ve örnek büyüklügünün uygunluğu hakkında bilgi verir. KMO değeri $=0.845>0.70$ olduğundan veri setinin Faktör analizi için uygun olduğu belirlenmiştir (Tablo 7).

Tablo 8. Ortak varyans

\begin{tabular}{|c|c|c|}
\hline & $\begin{array}{l}\text { Başlangıç değeri } \\
\text { (Initial) }\end{array}$ & Ortak varyans \\
\hline M1 & 0.363 & 0.417 \\
\hline M2 & 0.432 & 0.524 \\
\hline M3 & 0.312 & 0.345 \\
\hline M6 & 0.271 & 0.298 \\
\hline M8 & 0.407 & 0.502 \\
\hline M10 & 0.205 & 0.311 \\
\hline M11 & 0.248 & 0.393 \\
\hline M13 & 0.372 & 0.452 \\
\hline M17 & 0.285 & 0.424 \\
\hline M18 & 0.346 & 0.523 \\
\hline M19 & 0.227 & 0.314 \\
\hline M20 & 0.487 & 0.584 \\
\hline
\end{tabular}

Açıklayıcı Faktör Analizine ait Ortak varyans (Communality) tablosu incelendiğinde ortak varyans değeri 0.30'un altında olan M5, M9, M21, M12 ve M16 maddeleri analizden çıkarılmıştır. Çünkü bu değerler ne kadar yüksek ise toplam varyansı açıklama yüzdesi o kadar yüksek olur. Ayrıca başlangıç değerlerinin 1'in altında olması veri setinin çalışma için uygun olduğunu ifade etmektedir.

Tablo 9. Döndürülmüş faktör matrisi

\begin{tabular}{lccc}
\hline & \multicolumn{3}{c}{ Faktör } \\
\cline { 2 - 4 } M1 & 1 & 2 & 3 \\
\cline { 2 - 4 } M2 & 0.509 & & 0.393 \\
M3 & 0.708 & & \\
M6 & 0.488 & & 0.325 \\
M8 & 0.521 & & \\
M10 & 0.682 & & \\
M11 & & & 0.510 \\
M13 & 0.458 & & 0.583 \\
M17 & & 0.643 & 0.485 \\
M18 & & 0.688 & \\
M19 & & 0.552 & \\
M20 & 0.727 & & 0.220 \\
\hline
\end{tabular}

Döndürülmüş faktör matrisi tablosu incelendiğinde binişiklik probleminin olmadığg ve ölçekte yer alan maddelerin 3 faktör altında toplanabileceği görülmüştür. 1. faktör altında M1, M2, M3, M6, M8 ve M20; 2. faktör altında M17, M18 ve M19; 3. Faktör altında ise M10, M11 ve M13 maddelerinin yer aldığı elde edilmiştir. 
Binişiklik (ortak yüklenme) probleminde en yüksek ile en yükseğe yakın faktör yükleri arasındaki maddeler arasındaki fark incelenir. Bu fark 0 ile 0.10 arasında ise bu maddeler ortak yüklenmiştir ve analizden çıkarılır [22].

Tablo 10. Özdeğer istatistiğine bağl faktör sayısı ve açıklanan toplam varyans

\begin{tabular}{|c|c|c|c|c|c|}
\hline \multirow[b]{2}{*}{ Faktör } & \multicolumn{3}{|c|}{ Özdeğer } & \multicolumn{2}{|c|}{ Açıklanan toplam varyans } \\
\hline & Toplam & Varyans yüzdesi & $\begin{array}{c}\text { Birikimli varyans } \\
\text { yüzdesi }\end{array}$ & Varyans yüzdesi & $\begin{array}{c}\text { Birikimli varyans } \\
\text { yüzdesi }\end{array}$ \\
\hline 1 & 3.979 & 33.157 & 33.157 & 21.303 & 21.303 \\
\hline 2 & 1.723 & 14.356 & 47.513 & 10.925 & 32.229 \\
\hline 3 & 1.112 & 9.267 & 56.780 & 10.154 & 42.382 \\
\hline 4 & 0.768 & 6.400 & 63.180 & & \\
\hline 5 & 0.706 & 5.885 & 69.066 & & \\
\hline 6 & 0.679 & 5.661 & 74.726 & & \\
\hline 7 & 0.643 & 5.359 & 80.085 & & \\
\hline 8 & 0.596 & 4.964 & 85.049 & & \\
\hline 9 & 0.524 & 4.370 & 89.418 & & \\
\hline 10 & 0.470 & 3.917 & 93.335 & & \\
\hline 11 & 0.407 & 3.393 & 96.728 & & \\
\hline 12 & 0.393 & 3.272 & 100.000 & & \\
\hline
\end{tabular}

Tablo 10’a göre 12 maddelik ölçeğin, toplam varyansın \%42.38'ini açılkladığı elde edilmiştir.

Tablo 11. Güvenilirlik analizi

\begin{tabular}{lcc}
\hline & Cronbach alfa güvenilirlik katsayıs1 & Madde sayıs1 \\
\hline F1 & 0.805 & 6 \\
F2 & 0.674 & 3 \\
F3 & 0.603 & 3 \\
Ölçeğin geneli & 0.808 & 12 \\
\hline
\end{tabular}

Güvenilirlik analizi sonucunda çalışmada kullanılan ölçeğin yüksek bir güvenilirlik düzeyine sahip olduğu belirlenmiştir (Tablo 11).

Sonuç olarak; birinci faktör altındaki maddeler F1= M1, M2, M3, M6, M8, M20; ikinci faktör altındaki maddeler F2= M17, M18, M19 ve üçüncü faktör altındaki maddeler ise F3= M10, M11, M13 olarak belirlenmiştir.

Doğrulayıcı faktör analizi ile tek faktörlü, birinci düzey çok faktörlü ve ikinci düzey çok faktörlü modeller incelenmiştir. 


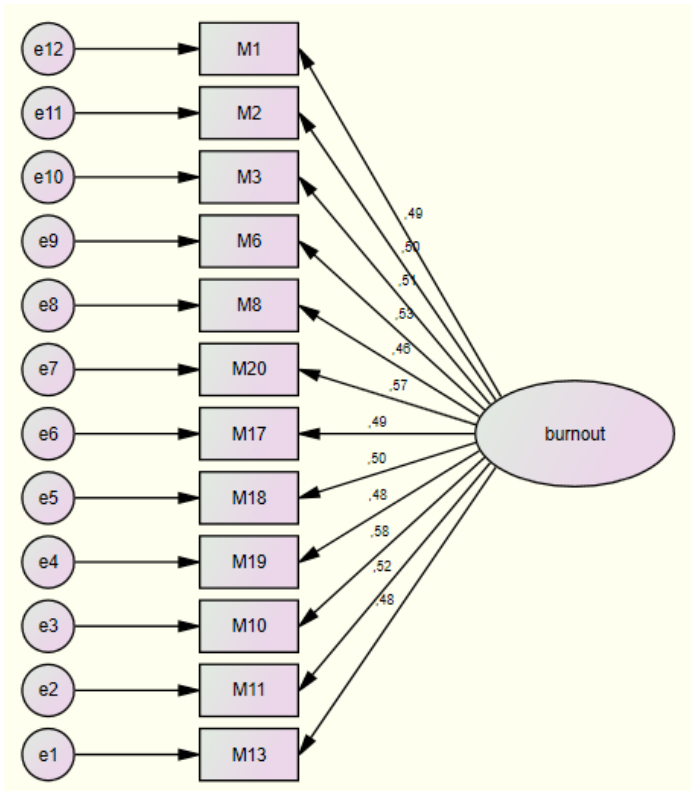

Şekil 1. Tükenmişlik (burnout) ölçeği için tek faktörlü model

Şekil 1'de tek faktörlü model incelenmiştir. Modelin esası, gözlenebilen tüm değişkenlerin, geniş ve daha kapsayıcı bir üst değişken (burnout) altında toplanmasıdır. Her bir maddeye ait katsayılar şekil üzerinde gösterilmiştir.

Birinci düzey çok faktörlü modelin esası, gözlenebilen değişkenlerin, birden fazla bağımsız boyut altında toplanmasıdır. Bu model araştırmacı tarafından tamamen teorik olarak belirlenip doğrulayıcı faktör analizi ile test edilmiş bir model olabileceği gibi, açıklayıcı faktör analizi sonucunda elde edilmiş bir model de olabilir. Bu çalışmada açıklayıcı faktör analizi sonucunda elde edilen faktörlere ait maddelere dayalı bir model oluşturulmuş ve Şekil 2'de gösterilmiştir.

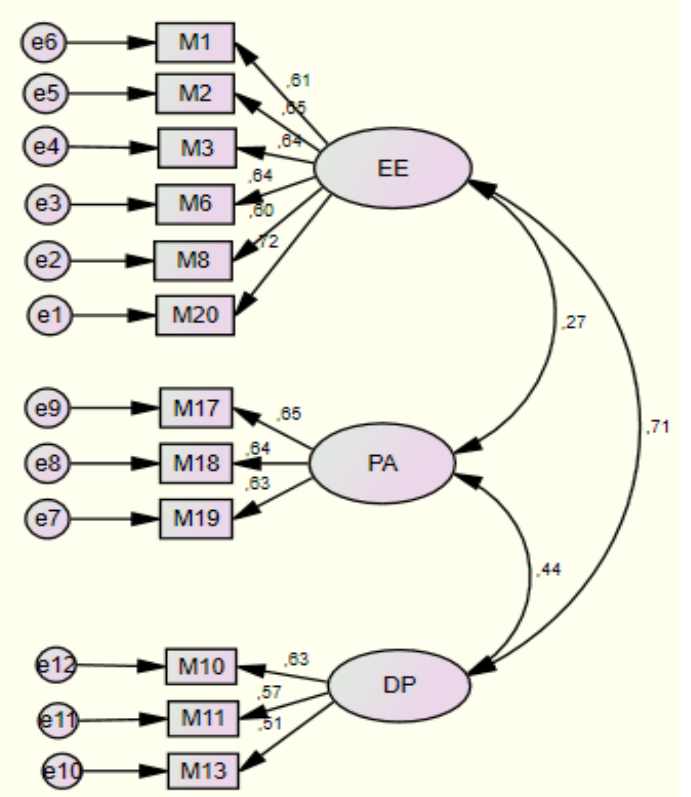

Şekil 2. Tükenmişlik (burnout) ölçeğinin duygusal tükenme (EE), kişisel başarı (PA) ve duyarsızlaşma (DP) alt boyutları için birinci düzey çok faktörlü model 
Maslach Tükenmişlik ölçeğini test etmek amacıyla birinci düzey doğrulayıcı faktör analizi yapılmıştır. Doğrulayıcı faktör analizi sonucunda ölçekte yer alan 12 ifadeye ait model uyum değerlerinin kabul edilebilir düzeyde olmadıkları görülmüştür (Tablo 12). Bu durumda modifikasyon indekslerinde iyileştirme yoluna gidilmelidir. İyileştirme yapılırken uyumu azaltan değişkenler belirlenmiş, artık değerler arasında kovaryansı yüksek olanlar için yeni kovaryanslar oluşturulmuştur. Elde edilen yeni model Şekil 3'deki gibidir. Sonrasında yenilenen uyum indisi hesaplamalarında uyum indisleri için kabul edilen değerler sağlanmış ve Tablo 12'de gösterilmiştir.

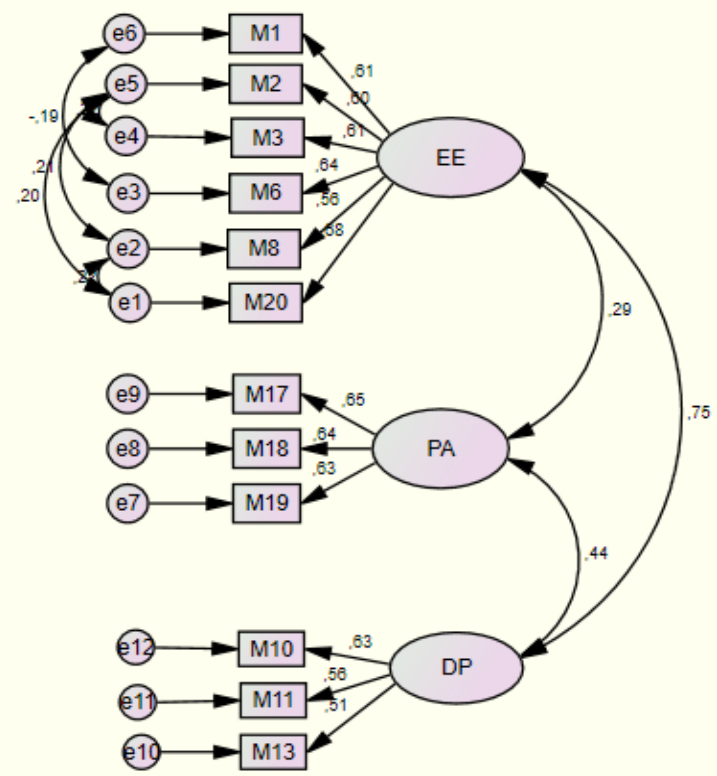

Şekil 3. Tükenmişlik (burnout) ölçeğinin duygusal tükenme (EE), kişisel başarı (PA) ve duyarsızlaşma (DP) alt boyutları için modifiye edilmiş birinci düzey çok faktörlü model

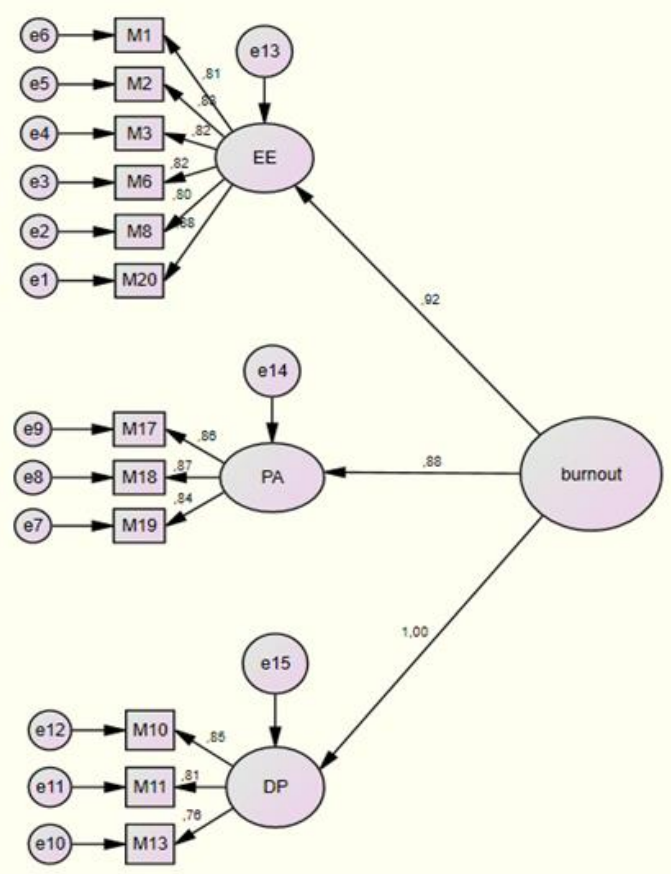

Şekil 4. Tükenmiş̧lik (burnout) ölçeğinin duygusal tükenme (EE), kişisel başarı (PA) ve duyarsızlaşma (DP) alt boyutları için ikinci düzey çok faktörlü model 
Analiz sonucunda önerilen modifikasyonlar yapılmıştır. Modifikasyon sonuçlarına Şekil 3'de yer verilmiştir. Doğrulayıcı faktör analizi sonucunda örnekleme ait verilerin orijinal faktör yapısına uyup uymadığ1 test edilmiştir. Modifikasyon sonucunda elde edilen modele ait değerlerin kabul edilebilir sınırlar içinde olduğu ise Tablo 12'de gösterilmiştir. Dolayısıyla Maslach tükenmişlik ölçeğinin üç faktörlü yapısı doğrulanmıştır.

Şekil 4'de Maslach Tükenmişlik ölçeği için ikinci düzey çok faktörlü model incelenmiştir. Bu modelin birinci düzey çok faktörlü modelden farkı, ölçeğinin kendisinin modele eklenmesidir. Bu modele ait uyum iyiliği indekslerinin kabul edilebilir sınırlar içinde olmadığı Tablo 12'de gösterilmiştir.

Doğrulayıcı Faktör Analizinde Ki-kare uyum testinin 2 ile 3 arasında olması, Yaklaşık Hataların Ortalama Karekökü (RMSEA) değerinin 0.08 değerini aşmaması; Karşılaştırmalı Uyum İndeksi (CFI, Comparative Fit Index) değerinin 0.85 veya 0.95 üzerinde olmas1; İyilik Uyum İndeksi (GFI, Goodness

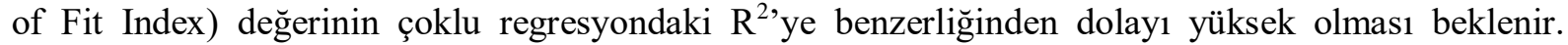
Bunlara ek olarak, 0 ile 1 arasında değişen değerler için sıfıra en yakın Ortalama Hataların Karekökü (SRMR) değerinin modele daha uygun olduğu bilinmektedir. Ayrıca en küçük Akaike Bilgi Kriteri (AIC, Akaike Information Criterion), Tutarlı Akaike Bilgi Kriteri (CAIC, Consistent Akaike Information Criterion), Beklenen Çapraz doğrulama İndeksi (ECVI, Expected Cross Validation Index) değerine sahip olan modelin gerçeğe en yakın model olduğu söylenir [24].

Tablo 12. Model Karşılaştırmaları ve Optimum Modelin Belirlenmesi

\begin{tabular}{lccccccccc}
\hline Model $^{*}$ & $\Delta \chi^{2}$ & $\Delta \chi^{2} / \mathrm{df}$ & RMSEA & CFI & GFI & SRMR & AIC & CAIC & ECVI \\
\hline Tek & 405.521 & 6.239 & 0.129 & 0.631 & 0.770 & 0.129 & 431.521 & 493.263 & 1.379 \\
Faktörlü & & & & & & & & & \\
Birinci & 159.895 & 2.665 & 0.073 & 0.892 & 0.920 & 0.076 & 195.895 & 281.384 & 0.626 \\
Düzey & & & & & & & & & \\
Modified & 126.329 & 2.297 & 0.063 & 0.928 & 0.942 & 0.072 & 172.329 & 281.565 & 0.551 \\
İkinci & 381.108 & 6.049 & 0.127 & 0.656 & 0.879 & 0.352 & 411.108 & 482.349 & 1.313 \\
Düzey & & & & & & & & & \\
\hline
\end{tabular}

": $\Delta \chi^{2}$ ki-kare fark istatistiği; $\Delta \chi^{2} / \mathrm{df}$ Ki-kare uyum testi; RMSEA = Yaklaşık Hataların Ortalama Karekökü; CFI= Karşılaştırmalı Uyum İndeksi; GFI= İyilik Uyum İndeksi; SRMR= Ortalama Hataların Karekökü; AIC= Akaike Bilgi Kriteri; CAIC= Tutarlı Akaike Bilgi Kriteri; ECVI= Beklenen Çapraz doğrulama İndeksi

Tablo 12 incelendiğinde Maslach tükenmişlik ölçeğinin modellenmesinde en uygun modellerin Birinci düzey çok faktörlü model ve bu modelin modifikasyonu ile elde edilen model olduğu belirlenmiştir. Birinci düzey çok faktörlü model ile iyileştirilmiş modeli karşılaştırmak için Ki-kare fark istatistiği kullanılarak optimum model aşağıdaki gibi elde edilmiştir.

$$
\begin{aligned}
& \Delta \chi^{2}=159.895-126.329=33.566 \\
& \Delta d f=60-55=5
\end{aligned}
$$

0.05 anlamlılık düzeyinde 5 serbestlik dereceli Ki-kare kritik değeri 11.07 olup $33.566>11.07$ olduğundan bu iki model arasında istatistiksel olarak anlamlı bir farklılık olduğu elde edilir. Dolayısıyla düzenleme yapılan (modifiye edilmiş) modelin uyum iyiliği değerleri daha uygun olduğundan bu modelin daha uygun olduğu söylenir.

\section{Sonuç ve Öneriler}

Çalışmada yapı geçerliliği için; öncelik sırasına göre aykırı (uç) değerler analizi, madde analizi, açıklayıcı faktör analizi ve güvenirlik analizi yapılmıştır. Çalışmada kullanılan Maslach Tükenmişlik ölçeği daha önce farklı araştırmalarda kullanılmış olduğundan, geçerliliğini test etmek amacı ile son olarak doğrulayıcı faktör analizi yapılmıştır. Doğrulayıcı faktör analizi ile yapısal modeller elde edilmiştir. Uyum indeksleri ile optimum model belirlenmiştir. Tükenmişlik ölçeği için; tek faktörlü, birinci düzey çok faktörlü ve ikinci düzey çok faktörlü modeller incelenmiştir. Çalışmanın sonuçlarına 
göre; verilerin modellenmesinde tek faktörlü ve ikinci düzey çok faktörlü modelin uygun olmadığ1 belirlenmiştir. Birinci düzey çok faktörlü modele ait Yaklaşık Hataların Ortalama Karekökü (RMSEA) değeri 0.073, Karşılaştırmalı Uyum İndeksi (CFI) değeri 0.892, İyilik Uyum İndeksi (GFI) değeri 0.920 ve Akaike Bilgi kriteri değeri 195.895 olarak elde edilmiştir. Daha sonra birinci düzey çok faktörlü model modifiye edilmiş ve RMSEA değeri 0.063 'e düşmüştür. CFI değeri 0.928 , GFI değeri ise 0.942 olarak belirlenmiştir. Sonuç olarak, modifiye edilmiş birinci düzey çok faktörlü modelin kullanılması önerilmektedir.

\section{Kaynaklar}

[1] Özdamar K. 2016. Eğitim, Sağlık ve Davranış Bilimlerinde Ölçek Ve Test Geliştirme Yapısal Eşitlik Modellemesi IBM SPSS, IBM SPSS AMOS ve MINITAB Uygulamall, Nisan Kitabevi, 286s. Eskișehir.

[2] Çelik H.E., Yılmaz V. 2016. Yapısal Eşitlik Modellemesi, Temel Kavramlar, Uygulamalar, Programlama, Anı Yayıncılık, 247s. Ankara.

[3] Wold H.O.A. 1954. Causality and Econometrics, Econometrica, 22: 162-177.

[4] Blalock H.M. 1971. Causal Models Involving Unmeasured Variables in Stimulus-response Situations, in Causal Models in the Social Sciences, New York:McGraw-Hill, 335-347.

[5] Malaeb Z.A., Summers, J.K., Pugesek, B. H. 2000. Using Structural Equation Modeling to Investigate Relationships Among Ecological Variables, Environmental and Ecological Statistics, 7 (1): 93-111.

[6] Sönmez F., Ülker M. 1999. Tir Buğdayında Tane Verimi ile Bazı Verim Öğeleri Arasindaki İlişkiler, Turkish Journal of Agriculture and Foresty, 23: 45-52.

[7] Yılmaz V. 2004. LISREL ile Yapısal Eşitlik Modelleri: Tüketici Şikâyetlerine Uygulanması, Anadolu Üniversitesi Sosyal Bilimler Dergisi, 4 (1): 77-90.

[8] Kılınç M. 2006. Dinlenme Evinin Çevresel Özelliklerinin ve Mekana Bağlanmanın Yaşlının Hayat Doyumu Üzerindeki Etkileri, Orta Doğu Teknik Üniversitesi, Sosyal Bilimler Enstitüsü, Yüksek Lisans Tezi, 93s, Ankara.

[9] Yılmaz V., Çelik H.E. 2005. Bankacılık Sektöründe Müşteri Memnuniyeti ve Bankaya Bağl1lık Arasındaki İlişkinin Yapısal Eşitlik Modelleriyle Araştırılması, VII. Ulusal Ekonometri ve İstatistik Sempozyumu, 26-27 Mayıs 2005, İstanbul.

[10] Alkan N. 2004. Bilişsel Değerlendirmeler, Duygular ve Başa Çıkma: Yapısal Eşitlik Tekniği ile Etkileşimsel Stress ve Başa Çıkma Modelinde İncelenmesi, Orta Doğu Teknik Üniversitesi, Sosyal Bilimler Enstitüsü, Doktora Tezi, 153s, Ankara.

[11] Şimşek G.G, Noyan F. 2008. İlçelerin Gelişmişlik İndekslerinin Oluşturulmasında Çok Aşamalı Doğrulayıcı Faktör Analizi Yaklaşımı, İstatistikçiler Dergisi, 7 (2): 113-117.

[12] Çerezci E.T. 2010. Yapısal Eşitlik Modelleri ve Kullanılan Uyum İyiliği İndekslerinin Karşılaştırılması, Gazi Üniversitesi, Fen Bilimleri Enstitüsü, Doktora Tezi, 167s, Ankara.

[13] Marsh H.W., Morin A.J., Parker P.D., Kaur G. 2014. Exploratory Structural Equation Modeling: An Integration of the Best Features of Exploratory and Confirmatory Factor Analysis, Annual Review of Clinical Psychology, 10: 85-110.

[14] Alkış, N. 2016. Bayes Yapısal Eşitlik Modellemesi: Kavramlar ve Genel Bakış, Gazi İktisat ve İşletme Dergisi, 2 (3):105-116.

[15] Karagöz Y., Ağbektaş A. 2016. Yapısal Eşitlik Modellemesi ile Yaşam Memnuniyeti Ölçeğinin Geliştirilmesi; Sivas İli Örneği, Bartın Üniversitesi İktisadi İdari Bilimler Fakültesi, 7 (13): 274290.

[16] Karagöz Y., Kıngır S., Güvendi F. 2016. Yapısal Eşitlik Modellemesi ile Hasta Memnuniyeti Ölçeğinin Geliştirilmesi, Bartın Üniversitesi İktisadi İdari Bilimler Fakültesi, 7 (13): 140-158.

[17] Uygungil S. 2017. Pozitif Psikolojik Sermaye ile Çalışan Tutumları Arasındaki İlişkilerin İncelenmesi: Adana İlinde Bir Uygulama. Atatürk Üniversitesi, Sosyal Bilimler Enstitüsü, Doktora Tezi, 258s, Erzurum.

[18] Samancı S. 2017. Örgütsel ve Kişisel Öncülleri Bağlamında Örgütsel Vatandaşlık Davranışı: Bir Model Testi, Türk Hava Kurumu Üniversitesi, Sosyal Bilimler Enstitüsü, Doktora Tezi, 210s, Ankara. 
[19] Topcu M.K., Beğenirbaş M., Turgut E. 2017. Örgütsel Sinizm, Zorunlu Örgütsel Vatandaşl1k Davranışları ve İş Tatmininin Bireysel İş Performansına Etkilerinin Belirlenmesine Yönelik İmalat Sanayide Bir Uygulama, Yönetim ve Ekonomi, 24(2):505-522.

[20] Kıran E. 2017. Örgütsel Sinizm ve İşe Gömülü Olmanın Psikolojik Sermaye ile İşten Ayrılma Niyeti Arasındaki İlişsideki Aracılık Rolü: Kamu Çalışanları Üzerine Bir Araştırma, Mustafa Kemal Üniversitesi, Sosyal Bilimler Enstitüsü, Yüksek Lisans Tezi, 118s, Hatay.

[21] Maslach C., Jackson SE. 1981. The Measurement of Experienced Burnout, Journal of Occupational Behaviour, 2(1): 99-113.

[22] Maslach C., Schaufeli WB., Leiter MP. 2001. Job Burnout, Annual Review Psychology, 52 (1): 397-422.

[23] Sümbüloğlu K, Sümbüloğlu V. 2013. Sağlık Bilimlerinde Araştırma Yöntemleri, 7. Bask1, Hatipoğlu Yayınevi, 208s, Ankara.

[24] Büyüköztürk Ş. 2011. Sosyal Bilimler İçin Veri Analizi El Kitabı: Istatistik, Araştırma Deseni SPSS Uygulamaları ve Yorum, PegemYayıncılık, 216s, Ankara. 